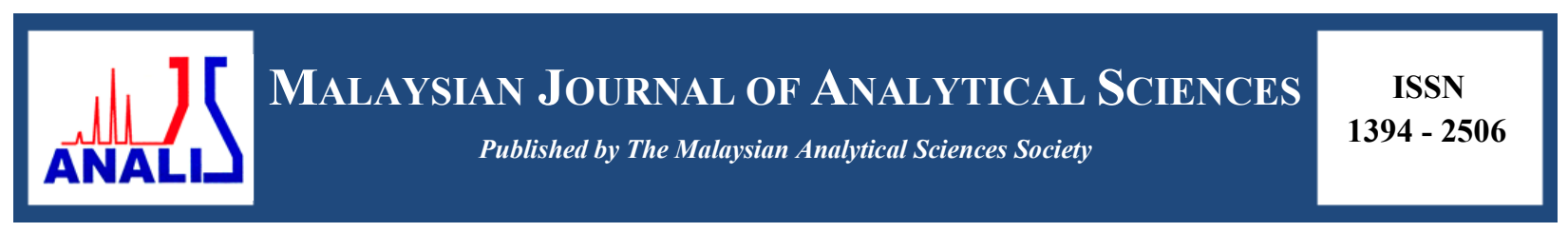

\title{
PLASTICIZING POLY(LACTIC ACID) USING EPOXIDIZED PALM OIL FOR ENVIRONMENTAL FRIENDLY PACKAGING MATERIAL
}

\section{(Peningkatan Fleksibiliti Poli(laktik asid) Menggunakan Minyak Kelapa Sawit Terepoksi untuk Aplikasi Pembungkus Mesra Alam)}

\author{
Fathilah Binti Ali ${ }^{1}$, Raina Jama Awale ${ }^{1}$, Hanan Fakhruldin ${ }^{1}$, Hazleen Anuar ${ }^{2}$ \\ ${ }^{1}$ Department of Biotechnology Engineering, Kulliyyah of Engineering \\ ${ }^{2}$ Department of Manufacturing and Materials Engineering, Kulliyyah of Engineering \\ International Islamic University of Malaysia, 53100 Kuala Lumpur, Malaysia \\ *Corresponding author: fathilah@iium.edu.my
}

Received: 10 June 2015; Accepted: 21 July 2016

\begin{abstract}
Petrochemical based polymers used in packaging materials are causing various environmental problems. Therefore, biopolymers prepared from renewable sources have high potential to substitute the commercially available non-degradable polymer. Poly(lactic acid) (PLA) is one of the biodegradable polymers that can be used to substitute in the application of petrochemicalbased polymers. Environmental friendly and biodegradable epoxidized palm oil (EPO) was used as plasticizer in this study and it was incorporated into PLA matrix through solution blending method. The mechanical properties were determined through three-point flexural test and tensile test. Tensile results revealed that the flexibility of PLA can be improved by the addition of epoxidized palm oil (EPO) as plasticizer in the polymer. PLA/EPO blend at ratio 100:10 showed significant flexibility among the other PLA/EPO blends. The thermal properties of neat PLA and PLA/EPO blends were characterized by using Differential Scanning Calorimetry (DSC). The glass transition temperature (Tg) decreased by addition of plasticizer, indicated the chain mobility of PLA increased in the PLA/EPO blends system. The improved flexibility of PLA by using EPO as plasticizer showed that it has high potential to be used as environmental-friendly packaging material.
\end{abstract}

Keywords: biodegradable polymer, green polymer, poly(lactic acid), environmental friendly packaging material

\section{Abstrak}

Barangan dari sumber yang boleh diperbaharui boleh mewujudkan satu platform untuk menggantikan polimer berasaskan petroleum yang diketahui tidak mampu terbiodegradasi. Poli(laktik asid) (PLA) adalah antara polimer yang boleh biodegradasi secara semula jadi dan dipercayai boleh menjadi pengganti bagi penggunaan polimer petrokimia. Pemplastik yang terbiodegradasi boleh digunakan untuk meningkatkan fleksibiliti PLA. PLA/EPO telah dicampurkan dengan nisbah tertentu dan sifat mekanikal dan haba bahan ini telah dikaji. Sifat mekanik polimer/pemplastik ditentukan melalui ujian lenturan mekanik dan ujian tegangan. Hasil kajian tegangan bahan menunjukkan bahawa fleksibiliti PLA boleh dipertingkatkan dengan penambahan minyak kelapa sawat terepoksi (EPO) sebagai pemplastik dalam polimer. Ia telah membuktikan bahawa kandungan 100:10 PLA/EPO adalah nisbah yang paling sesuai untuk campuran PLA/EPO. Ciri - ciri haba diperolehi dengan menggunakan Kalorimeter Pengimbasan Perbezaan (DSC). Pemplastik didapati mengurangkan suhu peralihan kaca PLA. EPO didapati meningkatkan tekanan tegangan dan pemanjangan di dalam PLA/EPO. Peningkatan fleksibiliti PLA menerusi penggunaan EPO membuktikan bahawa PLA/EPO boleh digunakan untuk pengunaan bungkusan mesra alam.

Kata kunci: polimer terbiodegradasikan, polimer hijau, poli(laktik asid), bungkusan mesra alam 


\section{Introduction}

Flexible materials for packaging industry have been second largest contributor in the industries from way back. Ease of handling and storage, overall cost savings and convenience are among the advantages of flexible packaging. Therefore, these are the keys for its success in packaging industry. There are many polymers that are used in flexible packaging industry but mostly the polymers are non-degradable. The most common polymers utilized in the industry are polypropylene (PP), polyethylene (PE), polyvinyl chloride (PVC), polyethylene terephthalate (PET), and bi-axially oriented polypropylene (BOPP) [1].

At present, most polymeric products are derived from fossil fuels, and these products become non- degradable waste materials and remain in the environment. Consequently, extensive researches are conducted globally to create green polymers from renewable resources which are biodegradable and compostable. Biodegradable polymer is an environmental friendly polymer and has low toxicity. But, it has lower strength, brittle, flammable and high permeability to most of gases and solvents as compared to metals and ceramics, which limits its applications in industry $[2,3]$. Reinforcement with additive polymers such as plasticizer and filler can overcome these problems, where the fillers need to be evenly distributed in the polymer matrix to maximize its function [3].

Biodegradable products have been used widely in food, furniture and clothing industries [5]. Therefore, the biopolymers have been researched extensively which can expand potential applications. According to Avérous and Pollet [4], biodegradable polymer is a material that decomposes into other resources such as carbon dioxide, methane, water, inorganic compounds and biomass. There are various types of biodegradable polymer which derived from renewable sources such as natural polymer (agro-polymer), microbial polymer (synthesis from microbial fermentation) and synthetic polymer (renewable bio-derived monomers) $[4,5,6]$.

Poly(lactic acid) (PLA) is a synthetic polymer that derived from renewable sources such as starch derivative. PLA is non-toxic and has high mechanical performance compared to other commercial polymers [7]. PLA can be used for disposable packaging industry as it has good mechanical properties and processability $[8,9]$. However, the brittleness of PLA causes main drawback in the packaging industry [8]. Thus, many researches have been conducted to improve mechanical properties by addition of plasticizer and fiber in the polymer matrices [9]. For this research, properties of PLA had been improved by the addition of epoxidized palm oil (EPO) as plasticizer through solution blending method. Different types of solvents were utilized to solubilize PLA, in which the solvents have closest solubility parameter with PLA. Therefore, the optimum solvent was chosen to be used for mixing PLA to EPO in various ratios. The optical, thermal and mechanical properties of PLA/EPO blends were reported and discussed.

\section{Screening process}

\section{Materials and Methods}

For screening process, the PLA beads were solubilized in different type of solvents such as chloroform, methylene chloride (DCM), dimethylformamide (DMF), tetrahydrofuran (THF) and toluene. The solvents were selected based on the solubility parameter. The PLA/EPO blends were blended at constant speed for overnight.

\section{Samples preparation}

Firstly, an amount $0.5 \mathrm{~g}$ of PLA was solubilized in five different solvents (chloroform, DCM, DMF, THF, and toluene). Then, $0.05 \mathrm{~g}$ of EPO was added into each sample and stirred overnight. The polymer blends were poured slowly into petri dishes and left evaporated at fume hood for 24 hours.

\section{Optimization and sample preparation}

Once the optimum solvent was chosen, $30 \mathrm{~g}$ of PLA was used to prepare PLA/EPO blends in five different ratios of PLA to EPO $(100: 5,100: 10,100: 15,100: 20$, and 100:30) and neat PLA as reference.

\section{Characterization}

$\mathrm{XH}-406 \mathrm{~B}$ Tablet Press Machine was used to prepare samples in $0.1 \mathrm{~cm}$ thickness of film at $150{ }^{\circ} \mathrm{C}$. Shimadzu Autograph AGS-X Series was used to measure the elongation-at-break of the samples. Differential Scanning Calorimetry (DSC 822) was used to obtain the thermal properties of the samples. 


\section{Solubility of PLA/EPO blend in different solvents}

\section{Results and Discussion}

Samples prepared in five different solutions was shown in Figure 1. This step is to identify the most optimum solvent that can be used for mixing and diffusivity of plasticizer in the PLA solution. Through optical observations, sample prepared from chloroform showed transparency and this indicated homogeneity of PLA and EPO in the solvent. Therefore, chloroform was chosen as the solvent and continued for next step of preparing PLA/EPO blend in different ratios.
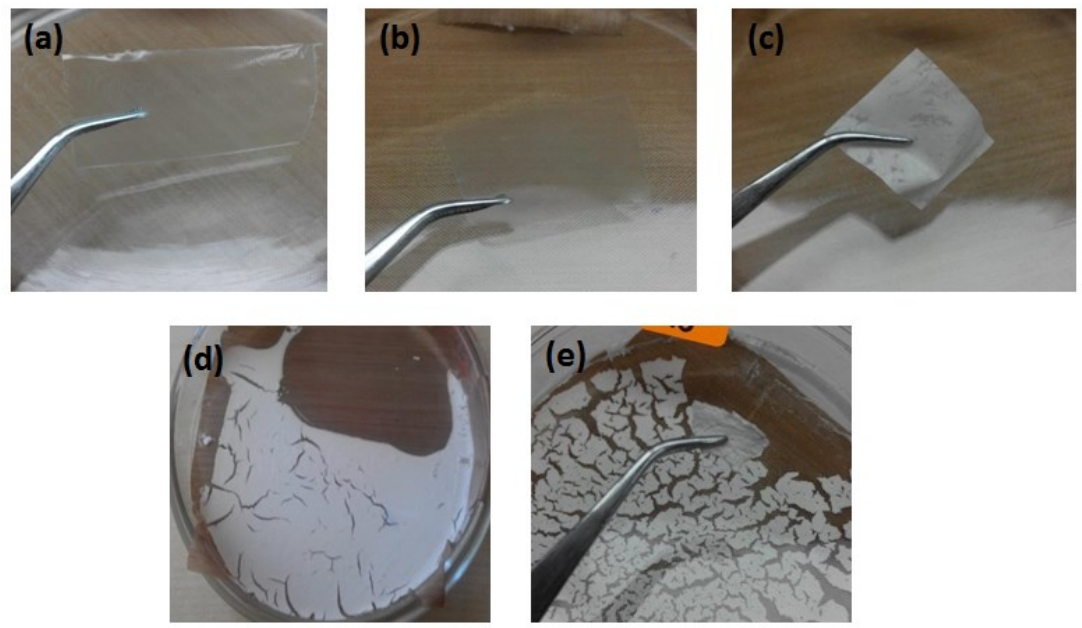

Figure 1. PLA/EPO (100:10) blends in different solutions (a) chloroform, (b) DCM, (c) THF, (d) DMF, and (e) toluene.

\section{Flexural properties of PLA/EPO blends}

Flexural strength is the limit of a material to withstand flexural stress without fail. The effects of EPO on the bending stress in the PLA/EPO blends was presented in Figure 2. The bending stress was increased from EPO 5 to EPO 10 and then reduced gradually to EPO content of 15 and $20 \mathrm{wt} \%$. And then, the stress increased again when the EPO content was $30 \mathrm{wt} \%$. This showed that by addition of EPO as plasticizer, it reduced the stress that the blend can endure except for PLA/EPO (100:10). At EPO content of $30 \mathrm{wt} \%$, the increased stress exhibited reduced plasticizing effect at higher loading of EPO. The stress also reflected the ability of PLA/EPO blend (100:10) to resist compression and tension stress simultaneously as shown in Figure 3.

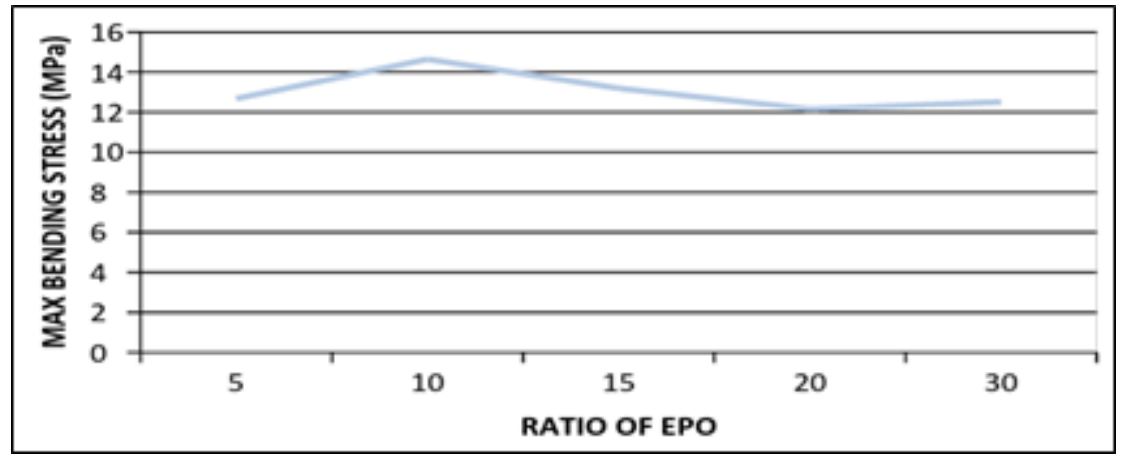

Figure 2. Bending stress of PLA/EPO blends at different ratios 

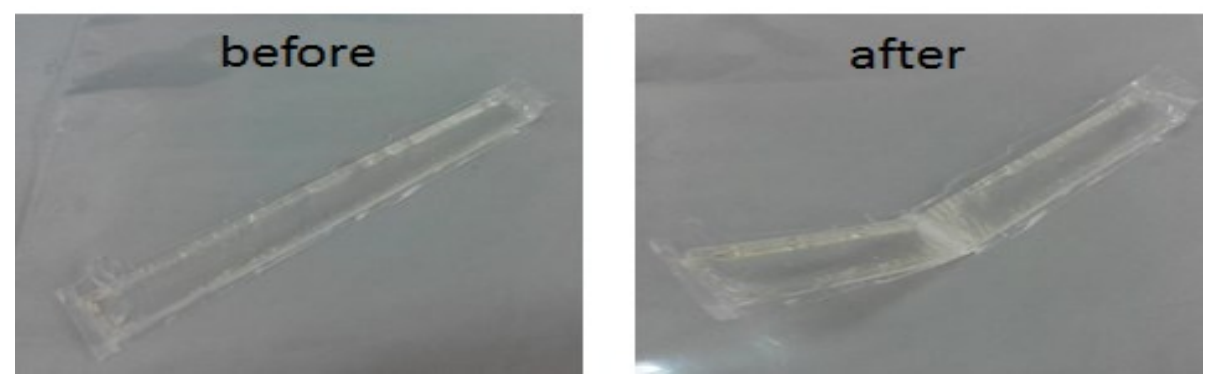

Figure 3. PLA/EPO blend (100:10) sample before and after the bending stress

\section{Tensile properties of PLA/EPO blends}

The tensile strength and elongation at break were determined at room temperature $\left(25^{\circ} \mathrm{C}\right)$. The stress-strain curves of neat PLA and PLA/EPO blends was shown in Figure 4. It showed that neat PLA was fractured at low strain whereas the PLA/EPO blends exhibited a ductile behavior with yield indicating plastic deformation behavior. PLA/EPO blends exhibited stress whitening behavior as shown in Figure 5. The similar stress whitening behavior was also observed in other plasticized PLA sample which was due to formation of voids in the samples [10].

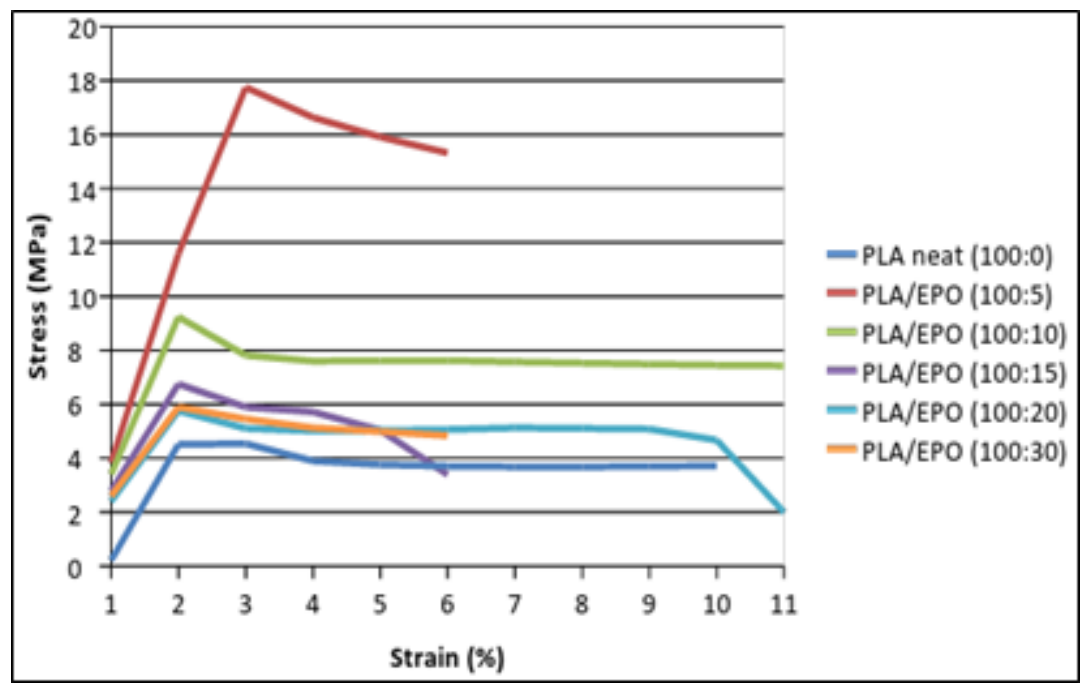

Figure 4. Stress-strain curves of neat PLA and PLA/EPO blends

The elongation-at-break of PLA/EPO blends increased due to plasticization effect of low molecular weight EPO and dispersion of EPO micro droplets in the PLA matrix [10]. The increased flexibility of the PLA/EPO blends was accompanied with decreased in tensile strength, yield stress and modulus. The yield stress of neat PLA decreased from 18.0 MPa to $9.0 \mathrm{MPa}$ for $5 \mathrm{wt} \%$ EPO. Addition of $5 \mathrm{wt} \%$ EPO significantly improved the tensile strength of PLA/EPO by approximately $50 \%$. Hence, as ratio of EPO increased, the yields stress decreased as reported by Chieng et. al [11]. Meanwhile, at EPO content of $30 \mathrm{wt} \%$, the yield stress decreased to $4.3 \mathrm{MPa}$ and elongation-atbreak of $6 \%$. The plasticizing effect reduced at higher loading of EPO, in this case, at $30 \mathrm{wt} \%$ the plasticizer has not much effect in the PLA matrix. 


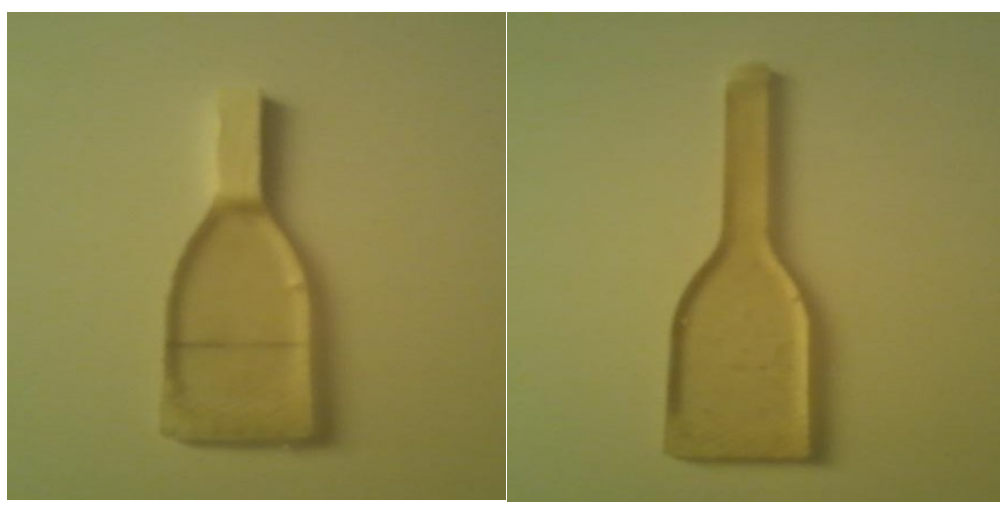

Figure 5. Visualization of deformed samples under tensile test

\section{Thermal properties of PLA/EPO blends}

The DSC heating thermograms of neat PLA and plasticized PLA blends was illustrated in Figure 6. The DSC curves exhibited three thermal transitions; glass transition $\left(T_{g}\right)$, crystallization $\left(T_{c}\right)$, and melting $\left(T_{m}\right)$ temperatures. The glass transitions of PLA/EPO blends appeared at a lower temperature compared to neat PLA. The glass transition temperatures gradually decreased with increasing EPO content. The $\mathrm{T}_{\mathrm{g}}$ of neat PLA decreased from 60.7 ${ }^{\circ} \mathrm{C}$ to $54.9{ }^{\circ} \mathrm{C}$ for PLA/EPO (100:15). However, for PLA/EPO (100:30), the glass transition temperature was increased to $60.84{ }^{\circ} \mathrm{C}$. Ali et al. [10] mentioned that there will be no more decrease of $\mathrm{T}_{\mathrm{g}}$ at greater amount of epoxidized soybean oil (ESO) in the PLA matrix. In addition, the declination of $\mathrm{T}_{\mathrm{g}}$ also exhibited mixing of EPO soft segments into the hard segment phase of PLA. The decrease in $T_{g}$ showed that there was penetration of EPO segment into the PLA hard segments and increased the chain mobility of PLA.

The crystallization temperature $\left(\mathrm{T}_{\mathrm{c}}\right)$ of PLA also decreased by addition of EPO which indicated higher chain mobility after the incorporation of EPO. This finding was consistent with plasticized PLA reported by Ali et al. [10], that the cold crystallization temperature of PLA decreased with higher plasticizer content.

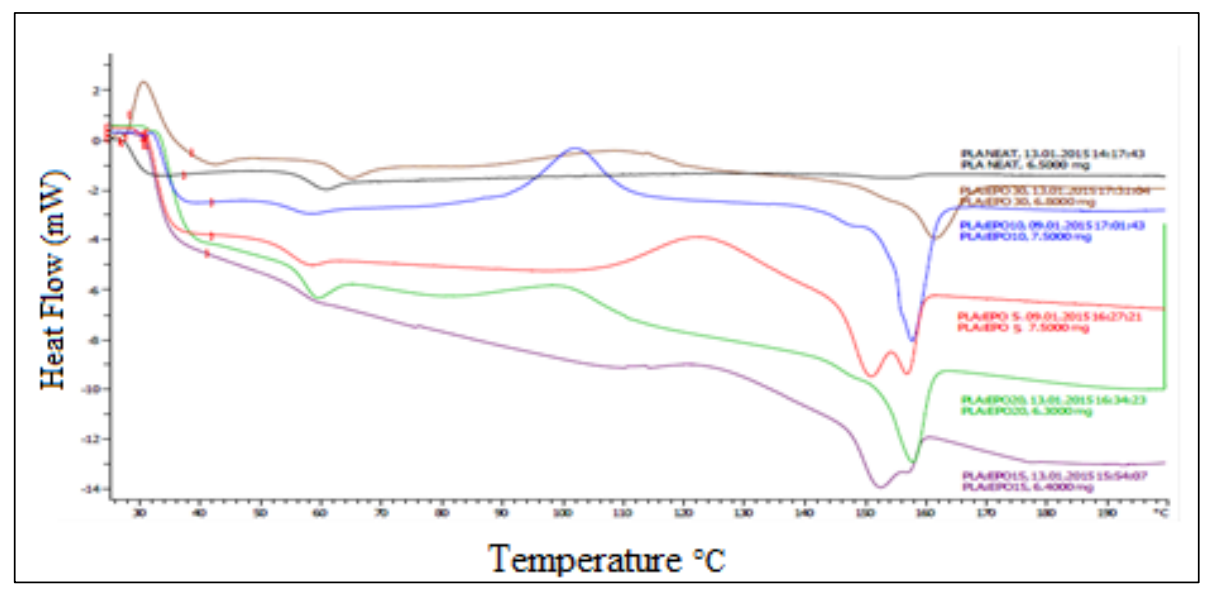

Figure 6. DSC thermograms of neat PLA and PLA/EPO blends 


\section{Conclusion}

Biodegradable PLA/EPO blend film was successfully prepared through solvent blending method by using chloroform. The flexibility of plasticized PLA increased by addition of EPO and the optimum ratio of EPO was 10 $w t \%$. Thermal properties of PLA/EPO blends showed that the glass transition $\left(\mathrm{T}_{\mathrm{g}}\right)$, crystallization $\left(\mathrm{T}_{\mathrm{c}}\right)$, and melting $\left(\mathrm{T}_{\mathrm{m}}\right)$ temperatures were decreased and the chain mobility of PLA increased. The improved thermal properties of PLA using EPO eased the processability of the blend and this to ensure the blend to be used as environmental friendly packaging material.

\section{Acknowledgement}

The author thanked International Islamic University of Malaysia (IIUM) and Kulliyyah of Engineering for the support and fund (EDW B14-131-1016). Mohd Hairi bin Mohd Rasit and Haji Sukiman Sengat are thanked for helping in flexural and thermal characterizations.

\section{References}

1. Erin, H. (2009). Flexible packaging: Innovations and developments. Italian Packaging Technology Award, (2): $16-17$.

2. Silverajah, V. G., Ibrahim, N. A., Wan Yunus, W., Abu Hassan, H. and Woei, C. B. (2012). A comparative study on the mechanical, thermal and morphological characterization of poly(lactic acid)/epoxidized palm oil blend. International Journal of Molecular Sciences, 13(5): 5878 - 5898.

3. Shirai, M., Grossmann, M., Mali, S., Yamashita, F., Garcia, P. and Müller, C. (2013). Development of biodegradable flexible films of starch and poly(lactic acid) plasticized with adipate or citrate esters. Carbohydrate Polymers, 92(1): 19 - 22.

4. Avérous, L. and Pollet, E. (2012). Biodegradable polymers. Environmental silicate nano-biocomposites. London: Springer-Verlag: pp. $14-39$.

5. Anne, B. (2011). Environmental-friendly biodegradable polymers and composites. Integrated Waste Management, 1: pp. 25.

6. Mitrus, M., Wojtowicz, A. and Moscicki, L. (2009). Biodegradable polymers and their practical utility. Thermoplastic starch. Weinheim: WILEY-VCH Verlag GmbH \& Co. KGaA: pp. 1 - 33.

7. Leja, K. and Lewandowicz, G. (2010). Polymer biodegradation and biodegradable polymers - A Review. Polish Journal of Environment Studies, 19(2): 255 - 266.

8. Al-Mullah, E. A. and Ibrahim, N. A. (2012). Poly(lactic Acid) as a biopolymer-based nano-composite. Products and Applications of Biopolymers, 28: pp 23.

9. Rasal, R. M., Janorkar, A. V. and Hirt, D. E. (2010). Poly(lactic acid) modifications. Progress in Polymer Science, 35(3): $388-356$.

10. Ali, F., Chang, Y. W., Kang, S. C. and Yoon, J. Y. (2008). Thermal, mechanical and rheological properties of poly (lactic acid)/epoxidized soybean oil blends. Polymer Bulletin, 62 (1): 91 - 98.

11. Chieng, B. W., Ibrahim, N. A., Then, Y. Y. and Loo, Y. Y. (2014). Epoxidized vegetable oils plasticized poly(lactic acid) biocomposites: mechanical, thermal and morphology properties. Molecules, 19: 16024 16038. 